\title{
ARTICLE
}

\section{Calibrating the chitons (Mollusca: Polyplacophora) molecular clock with the mitochondrial DNA cytochrome $C$ oxidase I gene}

Calibrando un reloj molecular para quitones (Mollusca: Polyplacophora) utilizando el gen mitocondrial que codifica para el citocromo oxidasa I

\author{
Cedar I. García-Ríos ${ }^{1}$, Nivette M. Pérez-Pérez ${ }^{1}$, \\ Joanne Fernández-López ${ }^{1}$ and Francisco A. Fuentes ${ }^{1}$
}

${ }^{1}$ Departamento de Biología, Universidad de Puerto Rico en Humacao, Avenida José E. Aguiar Aramburu, Carretera 908 km 1,2, Humacao, Puerto Rico. cedar.uprh@gmail.com

Resumen.- Especies hermanas separadas por el Istmo de Panamá se han utilizado para estimar tasas de evolución molecular. Un reloj molecular calibrado con un evento geológico bien estudiado puede ser de utilidad para proponer hipótesis sobre la historia evolutiva. El Istmo de Panamá emergió completamente hace 3,1 millones de años (m.a.), pero se ha evidenciado que comunidades asociadas a costas rocosas y arrecifes quedaron aisladas en fechas más tempranas (5,1-10,1 m.a.). Se determinó la divergencia de segmentos del gen mitocondrial citocromo oxidasa I (COI) para 2 pares de especies hermanas de quitones. El par Stenoplax purpurascens del Caribe y S. limaciformis del Pacífico oriental tropical, son especies muy similares fenotípicamente. Las especies del segundo par, Acanthochitona rhodea del sur del Caribe y $A$. ferreirai de las costas pacíficas de Panamá y Costa Rica, fueron tratadas como la misma especie hasta la reciente descripción de A. ferreirai. Utilizando ejemplares recolectados en ambas costas de Costa Rica se compararon secuencias homólogas del gen COI. Para el par de especies del género Stenoplax se determinó una divergencia total de 11,4\% pares de bases (bp). Para el par de especies del género Acanthochitona, se encontró una divergencia de 10,4-10,5\% bp. Estos valores de divergencia del COI permiten calcular razones de divergencia de 3,7\% / m.a. (aislación hace 3,1 m.a.) hasta 1,1\% / m.a. (aislación temprana). Esta es la primera calibración del gen col como reloj molecular para los poliplacóforos.

Palabras clave: Istmo de Panamá, reloj molecular, cOI, Stenoplax, Acanthochitona

\begin{abstract}
Sister species separated by the Isthmus of Panama have been used to estimate the rate of molecular evolution. A molecular clock calibrated with a well studied geological event can be useful to propose evolutionary history hypotheses. The Isthmus of Panama emerged completely 3.1 million years ago (mya), but fossil evidence has shown that rocky shore and reef mollusks communities were isolated early (5.1-10.1 mya). The divergence of segments of the mitochondrial gene cytochrome oxidase I (COI) was determined for 2 pairs of sister species of chitons. The pair Stenoplax purpurascens of the Caribbean and S. limaciformis of the tropical Eastern Pacific consists of phenotypically similar species. The species of the second pair, Acanthochitona rhodea from the south of the Caribbean and A. ferreirai of the Panama and Costa Rica Pacific coast, were treated as the same species until the recent description of A. ferreirai. Homologous fragments of the COI gene were compared using specimens collected on both coasts of Costa Rica. For the Stenoplax genus pair, a total divergence of $11.4 \%$ base pairs (bp) was determined. The Acanthochitona pair showed a divergence of $10.4-10.5 \%$ bp. These values allow calculated divergence rates from 3.7\% / mya (3.1 mya isolation) to $1.1 \%$ / mya (early isolation). This is the first calibration of the $\mathrm{COI}$ as a molecular clock for the polyplacophora.
\end{abstract}

Key words: Isthmus of Panama, molecular clock, COI, Stenoplax, Acanthochitona

\section{INTRODUCTION}

Molecular clocks are useful for determining the time during which phylogenetic events occur. A molecular divergence analysis, used to calibrate a molecular clock, requires the knowledge of 2 facts: first, the time at which species is genetically isolated to give rise to 2 sister species and secondly, the certainty that the sister species used for the calibration were isolated at that time, and not previously, through other speciation processes.

The Isthmus of Panama is a recent barrier that separated multiple populations of marine organisms, in what is today the Caribbean and tropical eastern Pacific (Knowlton \& Weigt 1998). It was assumed that the last moment of 
genetic exchange between populations of eastern tropical Pacific and Caribbean populations corresponds with the onset of the final closure of the Isthmus of Panama, which geological evidence situate at 3.1 million years ago (mya). The assumption that the sister species were isolated at the time when the exchange of seawater stopped completely (3.1 mya), was the hypothesis used by many researchers (Bermingham \& Lessios 1993, Schubart et al. 1998, Hellberg \& Vacquier 1999, McCartney et al. 2000, Haye et al. 2002, Collin 2003, Lessios et al. 2003, Morrison et al. 2004, Williams \& Reid 2004, Duda \& Kohn 2005, Duda \& Rolán 2005). However, other researchers propose dates prior to this one (Cronin \& Dowsett 1996, Knowlton $\&$ Weigt 1998, Marko 2002) arguing that because the lifting of the isthmus was gradual and the early stages of the water flow constriction could be barriers for some taxa, among them the deep-water fishes and the invertebrates intolerant to silt in their respiratory or filter structures (Coates \& Obando 1996, Collins 1996). Several researchers provide evidence suggesting that the sister species associated with reef habitat diverged earlier, as compared to the mangrove habitat species (Knowlton et al. 1993, Knowlton \& Weigt 1998, Lessios 2008, Miura et al. 2010). Considering gastropods (Tegula geminate pair) and bivalves (arcid) with fossil record for the calibration, Marko (2002) suggests that the divergence time for sister pairs of mollusks associated with rocky shore occurred between 5.1 to 10.1 mya.

The cytochrome oxidase I (COI) gene, can be used as a molecular chronometer, which is an appropriate tool to estimate the time at which gene flow was interrupted between 2 populations, given that the vicariant event occurred within a few million years (Knowlton \& Weigt 1998). Nuclear protein coding gene Histone H3 suffers substitutions less frequently, so it's not appropriate for the analysis of divergence for time periods of less than 30 mya (Marko 2002). The same applies to other nuclear ribosomal genes (18S rRNA, 28S rRNA) used for phylogenetic analyses (Clabaut et al. 2005). Thus, the rapidly evolving mitochondrial COI gene is robust for the interpretation of evolutionary relationships within genera.

Among mollusks, the percentage of divergence of COI gene across the Panamic Isthmus has been studied in gastropods sister species (Hellberg 1998, Collin 2003, Latiolais et al. 2006, Miura et al. 2010), also among bivalves (Marko 2002, Lee \& Foighil 2005). However, COI has not been used yet to specifically compare sister species in chitons.
According to Mayr (1969), sister species are pairs or groups of closely related species that are reproductively isolated, but are morphologically identical or nearly identical. Prior to biochemical comparisons, the criterion for proposing that a pair of chiton species were likely sister species was the demonstration of strong morphological similarity (Ferreira 1978, Bullock 1985, Lyons 1998). The putative sister species of chitons, Stenoplax purpurascens (Adams, 1845) (Caribbean) and S. limaciformis (Sowerby, 1832) (Pacific Ocean), are so similar in general form, size, shape and proportions of the valves, tegmentum sculpture and colors, shape and size of girdle scales that until recently they were classified as the same species (Ferreira 1978, Kaas \& Van Belle 1980) (Fig. 1). Bullock (1985) documented subtle differences in the sculpture of the valves, the morphology of the radula, and in esthetes pore densities, which justified treating $S$. purpurascens as distinct from the older species named, S. limaciformis.

In a taxonomic revision of the polyplacophora of the Caribbean region, Kaas (1972) recognized that Acanthochitona hemphilli and A. rhodea as similar species in size $(4-5 \mathrm{~cm})$, coloration, 18 tufs with around 50 large spicules in the girdle and not rounded tegmental pustules. Acanthochitona hemphilli (Pilsbry, 1893) with a North Caribbean distribution and A. rhodea (Pilsbry, 1893 ) in the South (Kaas 1972). Both are so similar that Watters (1981) declared A. rhodea to the synonymy of $A$. hemphilli. Ferreira (1985) proposed A. hemphilli as a synonym of $A$. rhodea (invert the synonymy). Both researchers did not recognize morphological differences that would justify their classification as different species. A. rhodea was also present in the eastern tropical Pacific (Smith, 1961, Keen 1971). Ferreira (1985) considered the species complex as one, with distribution from Florida to Brazil in the Western Atlantic, and from Mexico to Peru in the Pacific. Lyons (1988) using scanning electron microscope (SEM) analysis of the valves and girdle elements, sort out their consistent morphological differences of the two Caribbean species and describe a third species: A. ferreirai (Lyons, 1988) as the Pacific member of the complex (Fig. 2). Lyons (1988) expressed the hypothesis of greater closeness between the $A$. rhodea and A. ferreirai pair.

The objective of this study was to use partial COI sequences of two pairs of chitons sister species to determine how many base substitutions have accumulated after the Panamic Isthmus separated them. With the rate of divergence of these two pairs, this gene 


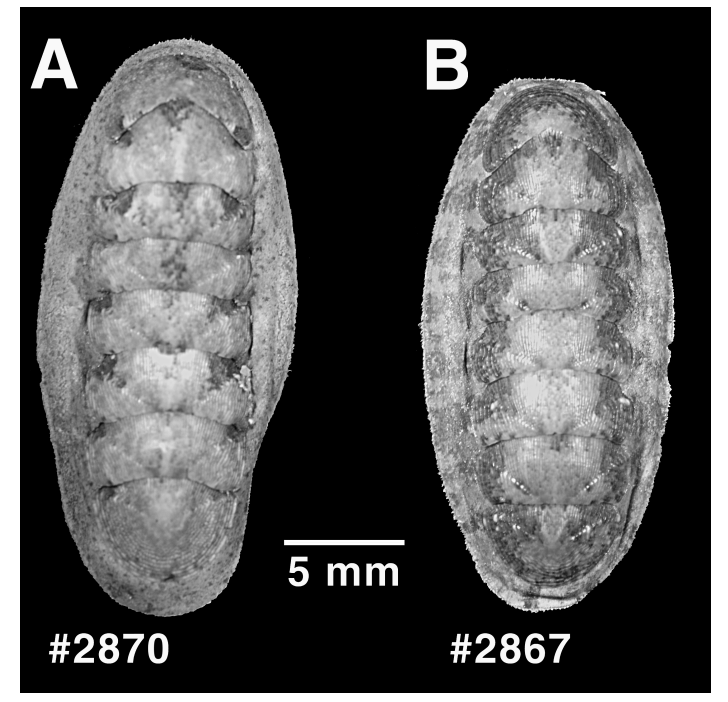

Figure 1. Dorsal view. A) Stenoplax limaciformis (Sowerby, 1832), CBUPRH \#2870; B) Stenoplax purpurascens (CB Adams, 1845), CBUPRH\# 2867 / Vista dorsal. A) Stenoplax limaciformis (Sowerby, 1832), CBUPRH \#2870; B) Stenoplax purpurascens (CB Adams, 1845), CBUPRH\# 2867

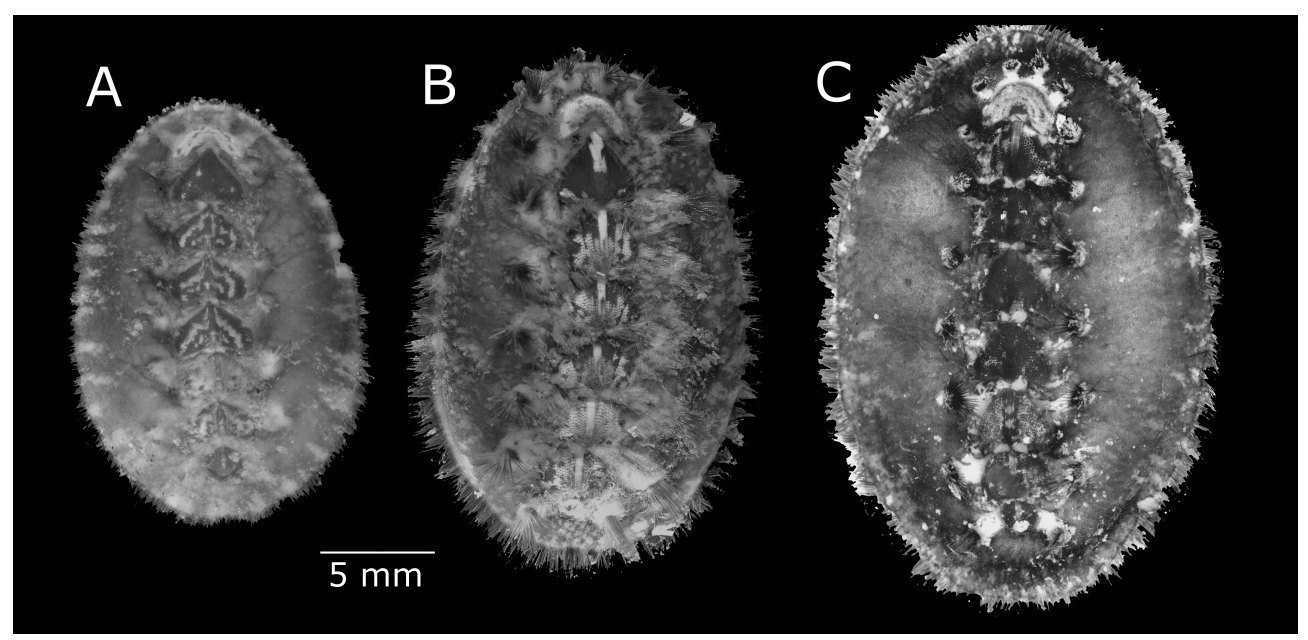

Figure 2. Dorsal view. A) Acanthochitona ferreirai (Lyons, 1988), CBUPRH\# 3148; B) Acanthochitona rhodea (Pilsbry, 1893), CBUPRH\# 2694; C) Acanthochitona hemphilli (Pilsbry, 1893), CBUPRH\# 2500 / Vista dorsal. A) Acanthochitona ferreirai (Lyons, 1988), CBUPRH\# 3148; B) Acanthochitona rhodea (Pilsbry, 1893), CBUPRH\# 2694; C) Acanthochitona hemphilli (Pilsbry, 1893), CBUPRH\# 2500 
can be calibrated as a molecular clock. Knowledge of this divergence ratio will allow us to estimate divergence times for other chitons species.

\section{Materials AND METHODS}

\section{SPECIMEN's COLLECTION}

The specimens used to compare the sister species were collected in Costa Rica. Specimens of the Pacific coast were obtained in Samará Bay (9॰52’29"N, 85³1’57.24"W), Guanacaste, in April 4, 2009. The specimens from the Caribbean coast were collected in Punta Puerto Vargas

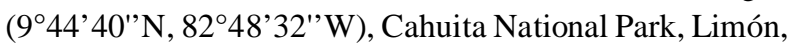

in April 9, 2009. The description of the collection stations and other associated species appear in Jörger et al. (2008), for the Pacific Coast, and in García-Ríos \& Alvarez-Ruiz (2011), for the Caribbean coast. To evaluate the intraspecific variability of the gene, we included samples obtained in Puerto Rico and Colombia. Other species of the 2 compared genera collected from Bonaire, Puerto Rico and Florida were also included. Sequences from 3 Pacific species of the genus Stenoplax, deposited in the GenBank by other authors, were used to corroborate the close genetic affinities between putative sister species (Table 1).

Table 1. List of specimens and GenBank accession numbers / Lista de ejemplares y el número de acceso al GenBank

\begin{tabular}{|c|c|c|c|}
\hline Species & Locality & Access $\mathrm{N}^{\circ}$ & CBUPRH ${ }^{\circ}$ \\
\hline S. purpurascens & Costa Rica - Caribbean, $9^{\circ} 44^{\prime} 40^{\prime \prime} \mathrm{N} ; 82^{\circ} 48^{\prime} 32^{\prime \prime} \mathrm{W}$ & KC669552 & 2683 \\
\hline S. purpurascens & Costa Rica - Caribbean, $9^{\circ} 44^{\prime} 40^{\prime \prime} \mathrm{N} ; 82^{\circ} 48^{\prime} 32^{\prime \prime} \mathrm{W}$ & KC669553 & 2806 \\
\hline S. purpurascens & Costa Rica - Caribbean, $9^{\circ} 44^{\prime} 40^{\prime \prime} \mathrm{N} ; 82^{\circ} 48^{\prime} 32^{\prime \prime} \mathrm{W}$ & KC669554 & 2851 \\
\hline S. purpurascens & Puerto Rico - Caribbean, $17^{\circ} 56^{\prime} 29^{\prime \prime N} ; 67^{\circ} 5^{\prime} 10^{\prime \prime} \mathrm{W}$ & KC669555 & 2712 \\
\hline S. purpurascens & Puerto Rico - Caribbean, $17^{\circ} 56^{\prime} 23^{\prime \prime N} ; 67^{\circ} 4^{\prime} 6^{\prime \prime W}$ & KC669556 & 2715 \\
\hline S. purpurascens & Puerto Rico - Caribbean, $17^{\circ} 56^{\prime} 23^{\prime \prime N}$; 6704'6"W & KC669557 & 2802 \\
\hline S. purpurascens & Colombia - Caribbean, $11^{\circ} 19^{\prime} 41^{\prime \prime} \mathrm{N} ; 74^{\circ} 4^{\prime} 40^{\prime \prime} \mathrm{W}$ & KC669558 & 2867 \\
\hline S. floridana & Florida - Caribbean, $24^{\circ} 42^{\prime} 14^{\prime \prime N} ; 81^{\circ} 9^{\prime} 22^{\prime \prime} \mathrm{W}$ & KC669562 & 2804 \\
\hline S. floridana & Florida - Caribbean, $24^{\circ} 42^{\prime} 14^{\prime \prime N} ; 81^{\circ} 9^{\prime} 22^{\prime \prime} \mathrm{W}$ & KC669563 & 2852 \\
\hline S. limaciformis & Costa Rica - Pacific, 952'29"N; 85³1'57.24"W & KC669559 & 2682 \\
\hline S. limaciformis & Costa Rica - Pacific, 952'29"N; 85³1'57.24"W & KC669560 & 2871 \\
\hline S. limaciformis & Costa Rica - Pacific, 952'29"N; 85³1'57.24"W & KC669561 & 2872 \\
\hline S. alata* & Indonesia & AY377711.1 & $\mathrm{n} / \mathrm{a}$ \\
\hline S. mariposa* & Eastern Pacific, $31.3^{\circ}-24.15^{\circ} \mathrm{N}$ & EF201016.1 & $\mathrm{n} / \mathrm{a}$ \\
\hline S. conspicua* & Eastern Pacific, $33.75^{\circ}-29^{\circ} \mathrm{N}$ & EF200986.1 & $\mathrm{n} / \mathrm{a}$ \\
\hline A. rhodea & Costa Rica - Caribbean, $9^{\circ} 44^{\prime} 40^{\prime \prime} \mathrm{N} ; 82^{\circ} 48^{\prime} 32^{\prime \prime} \mathrm{W}$ & KC669564 & 2748 \\
\hline A. hemphilli & Puerto Rico - Caribbean, $17^{\circ} 56^{\prime} 37^{\prime \prime N} ; 67^{\circ} 3^{\prime} 24^{\prime \prime W}$ & KF184977 & 3078 \\
\hline A. hemphilli & Puerto Rico - Caribbean, $17^{\circ} 56^{\prime} 37^{\prime \prime N} ; 67^{\circ} 3^{\prime} 24^{\prime \prime} \mathrm{W}$ & KF184978 & 3079 \\
\hline A. hemphilli & Puerto Rico - Caribbean, $17^{\circ} 56^{\prime} 23^{\prime \prime N}$; 674' $6^{\prime \prime} \mathrm{W}$ & KC669566 & 2713 \\
\hline A. hemphilli & Bonaire-Caribbean, $12^{\circ} 14^{\prime} 27^{\prime \prime} \mathrm{N} ; 68^{\circ} 24^{\prime} 44^{\prime \prime} \mathrm{W}$ & KC669567 & 2547 \\
\hline A. ferreirai & Costa Rica -Pacific, $9^{\circ} 52^{\prime} 29^{\prime \prime N}$; 85³1'57.24"W & KC669568 & 2811 \\
\hline A. ferreirai & Costa Rica -Pacific, $9^{\circ} 52^{\prime} 29^{\prime \prime N}$; 85³1'57.24"W & KC669569 & 2854 \\
\hline A. ferreirai & Costa Rica -Pacific, $9^{\circ} 52^{\prime 2} 29^{\prime \prime N} ; 85^{\circ} 31^{\prime} 57.24^{\prime \prime} \mathrm{W}$ & KC669570 & 2855 \\
\hline A. balesae & Colombia - Caribbean, $11^{\circ} 12^{\prime} 25^{\prime \prime} \mathrm{N} ; 7^{\circ} 13^{\prime} 49^{\prime \prime} \mathrm{W}$ & KF184979 & 2816 \\
\hline A. lineata & Puerto Rico - Caribbean, $17^{\circ} 56^{\prime} 22 " \mathrm{~N} ; 67^{\circ} 5^{\prime} 13^{\prime \prime} \mathrm{W}$ & KF184980 & 2731 \\
\hline A. lineata & Puerto Rico - Caribbean, $17^{\circ} 57^{\prime} 27^{\prime \prime N} ; 67^{\circ} 2^{\prime} 32^{\prime \prime} \mathrm{W}$ & KF184981 & 2845 \\
\hline A. pygmaea & Puerto Rico - Caribbean, $17^{\circ} 57^{\prime} 16^{\prime \prime N}$; $67^{\circ} 3^{\prime} 5^{\prime \prime} \mathrm{W}$ & KF184982 & 2810 \\
\hline C. lata & Puerto Rico - Caribbean, $17^{\circ} 57^{\prime} 27^{\prime \prime N}$; 67²'32"W & KF184983 & 2823 \\
\hline C. floridanus & Puerto Rico - Caribbean, $17^{\circ} 57^{\prime} 27^{\prime \prime N}$; 67²'32"W & KF184984 & 2809 \\
\hline C. tuberculatus & 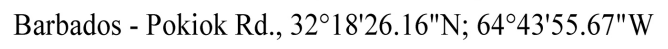 & KJ909661 & 3068 \\
\hline
\end{tabular}

*COI sequences and collection data obtained from the GenBank 
For the evaluation of the genetic similarity of the acanthochitonids we included other 6 species of the family: Acanthochitona balesae Abbot, 1954; A. hemphilli (Pilsbry, 1893), A. lineata Lyons, 1988; A. pygmaea (Reeve, 1847); Choneplax lata (Guilding, 1829) and Cryptoconchus floridanus (Dall, 1889). The specimens collected for this study were relaxed with ice, tied flat on a slide and preserved by total immersion in 95\% ethanol. Species were identified according to Bullock (1985) and Lyons (1988). The specimens for each DNA sequence were deposited in the Colección Biológica de la Universidad de Puerto Rico en Humacao (CBUPRH). The collection numbers, location and the access number of to the sequence in GenBank are shown in Table 1. More collection data is available in the GenBank specimen information field.

\section{Molecular data COLLECTION}

DNA extraction was performed using the QIAGEN DNeasy Blood \& Tissue Kit. From each specimen about 10 to $15 \mathrm{mg}$ of foot muscles were extracted. The DNA extracted was diluted in sterile water $(200 \mu \mathrm{l})$ and kept at $4^{\circ} \mathrm{C}$. An average of $700 \mathrm{ng}^{\mathrm{l}} \mathrm{l}^{-1}$ of DNA was obtained from each specimen.

The polymerase chain reaction (PCR) was performed using the extracted DNA and the COI universal primers: LCO 1490 (5'-GGTCAACAAATCATAAAGATATTGG3') and HCOI 2198 (5'-TAAACTTCAGGGTGACCA AAAAATCA-3') (Folmer et al. 1994). PCR reactions (25 $\mu \mathrm{l})$ included $0.5 \mu \mathrm{l}$ of the template DNA, $0.5 \mu \mathrm{l}$ of each primer $\left(5 \mathrm{pmol} \mu \mathrm{l}^{-1}\right), 2 \mu \mathrm{l}$ of dNTP blend ( $2.5 \mathrm{mM}$ each), $5 \mu \mathrm{l}$ PCR buffer (5X) (Promega), $2.5 \mu \mathrm{l}$ of $2.5 \mathrm{mM} \mathrm{MgCl}_{2}$ (Promega), and $0.25 \mu \mathrm{l}$ of Taq DNA polymerase $\left(5 \mathrm{U}^{\mathrm{l}^{-1}}\right)$ (Promega). The PCR reactions were carried out using an Applied Biosystems thermal cycler model 2720. Thermal cycling conditions involved an initial denaturation of 5 min at $95^{\circ} \mathrm{C}$, followed by 35 cycles including denaturation at $95^{\circ} \mathrm{C}$ for $30 \mathrm{~s}$, annealing ranging from 45 to $50^{\circ} \mathrm{C}$ for 30 $\mathrm{s}$, and extension at $72^{\circ} \mathrm{C}$ for $1 \mathrm{~min}$, with a final extension step at $72^{\circ} \mathrm{C}$ for $1 \mathrm{~min}$.

The PCR products were purified by precipitation with polyethylene glycol (PEG) precipitation. DNA sequencing was performed with a multicapillary sequencer (16) ABI PRISM 3130XL (Applied Biosystems) at the Sequencing and Genotyping Facility (SGF) of the University of Puerto Rico. The sequencing cycling conditions were: $96^{\circ} \mathrm{C}$ for 5 min, followed by 45 cycles of $96^{\circ} \mathrm{C}$ for $10 \mathrm{~s}, 50^{\circ} \mathrm{C}$ for $5 \mathrm{~s}$, $60^{\circ} \mathrm{C}$ for $4 \mathrm{~min}$, and indefinite hold at $4^{\circ} \mathrm{C}$.

\section{EDiting AND ANALYSIS OF THE NUCLEOTIDE SEQUENCES}

Consensus sequences were determined by aligning at least two sequences from opposite directions, using the program BioEdit 7.0.9.0 (Hall 1999). All the substitutions were corroborated using the chromatograms. The resulting sequences were aligned using ClustalW 1.4 (Thompson et al. 1994), included in the program BioEdit. Alignments were corrected manually and ambiguously aligned regions were not used in the analysis. Sequence comparisons between pairs were performed using the program MEGA4 (Tamura et al. 2007). For the determination of distance between species, the percent of difference was determined using all the available bases in equal length sequences. This was the basis for subsequent phylogenetic analyzes.

DNA saturation analysis was determined graphically by plotting the transition rate / transversion rate ratio as a function of percentage divergence (Roe \& Sperling 2007). Phylogenetic analyzes and the resulting trees were prepared using the Neighbor-Joining method (Saitou \& Nei 1987) with bootstrap replications (1000 replicates) (Felsenstein 1985), as implemented in MEGA4.

\section{Editing AND ANALYSIS OF THE AMINO ACID SEQUENCES}

The program MEGA4 was used to determine the amino acid sequences resulting from the translation of the gene fragments, using the invertebrate mitochondrial genetic code.

\section{Results}

The sequences of the COI gene among the sister species Stenoplax limaciformis and S. purpurascens showed 102 variable positions in the pairwise array of 642 aligned sites (about 16\%). The total number of variable positions in the pairwise array of 642 aligned sites was 102 (about $16 \%)$. The comparison includes 3 specimens of $S$. purpurascens collected from three separated localities within the Caribbean: Costa Rica, Colombia and Puerto Rico. The minimum differences between the specimens of Puerto Rico and the ones from Colombia and Costa Rica are 6.2 and 6.7\%, respectively. Among the specimens from Colombia and Costa Rica there is a divergence of $2.2 \%$. The closest genetic similarity of $S$. limaciformis was with the specimens of $S$. purpurascens from Costa Rica, $11.4 \%$ divergence (0.013 SE) (Table 2, Fig. 3). 
Table 2. Stenoplax sister species nucleotide percent distances. Below the diagonal: percent distances calculated comparing 642 bp (initial

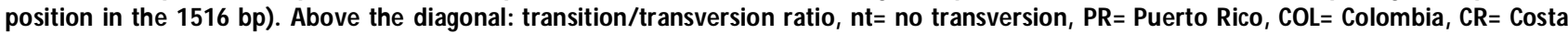
Rica / Porcentaje de diferencia en nucleótidos entre especies hermanas del género Stenoplax. Bajo la diagonal: porcentaje de diferencias en nucleótidos comparando 642 bp (iniciando en la base 1516). Sobre la diagonal: relación de transición/transversión, nt= ninguna transversión, $\mathrm{PR}=$ Puerto Rico, $\mathrm{COL}=$ Colombia, $\mathrm{CR}=$ Costa Rica

\begin{tabular}{|c|c|c|c|c|c|c|c|c|c|c|}
\hline & 1 & 2 & 3 & 4 & 5 & 6 & 7 & 8 & 9 & 10 \\
\hline [ 1] \#2712 S. purpurascens-PR & & nt & nt & 19.0 & 21.0 & 21.0 & 21.0 & 9.0 & 9.0 & 9.0 \\
\hline [2] \#2715 S. purpurascens-PR & $0.2 \%$ & & $\mathrm{nt}$ & 19.5 & 20.5 & 20.5 & 20.5 & 8.9 & 8.9 & 8.9 \\
\hline [ 3] \#2802 S. purpurascens-PR & $0.3 \%$ & $0.2 \%$ & & 20.0 & 21.0 & 21.0 & 21.0 & 9.0 & 9.0 & 9.0 \\
\hline [ 4] \#2867 S. purpurascens-COL & $6.2 \%$ & $6.4 \%$ & $6.5 \%$ & & $\mathrm{nt}$ & $\mathrm{nt}$ & $\mathrm{nt}$ & 6.7 & 6.7 & 6.7 \\
\hline [ 5] \#2683 S. purpurascens-CR & $6.9 \%$ & $6.7 \%$ & $6.9 \%$ & $2.2 \%$ & & nt & $\mathrm{nt}$ & 6.3 & 6.3 & 6.3 \\
\hline [ 6] \#2806 S. purpurascens-CR & $6.9 \%$ & $6.7 \%$ & $6.9 \%$ & $2.2 \%$ & $0.0 \%$ & & nt & 6.3 & 6.3 & 6.3 \\
\hline [7] \#2851 S. purpurascens-CR & $6.9 \%$ & $6.7 \%$ & $6.9 \%$ & $2.2 \%$ & $0.0 \%$ & $0.0 \%$ & & 6.3 & 6.3 & 6.3 \\
\hline [ 8] \#2682 S. limaciformis-CR & $12.5 \%$ & $12.3 \%$ & $12.5 \%$ & $12.0 \%$ & $11.4 \%$ & $11.4 \%$ & $11.4 \%$ & & $\mathrm{nt}$ & nt \\
\hline [9] \#2871 S. limaciformis-CR & $12.5 \%$ & $12.3 \%$ & $12.5 \%$ & $12.0 \%$ & $11.4 \%$ & $11.4 \%$ & $11.4 \%$ & $0.0 \%$ & & nt \\
\hline [10]\#2872 S. limaciformis-CR & $12.5 \%$ & $12.3 \%$ & $12.5 \%$ & $12.0 \%$ & $11.4 \%$ & $11.4 \%$ & $11.4 \%$ & $0.0 \%$ & $0.0 \%$ & \\
\hline
\end{tabular}

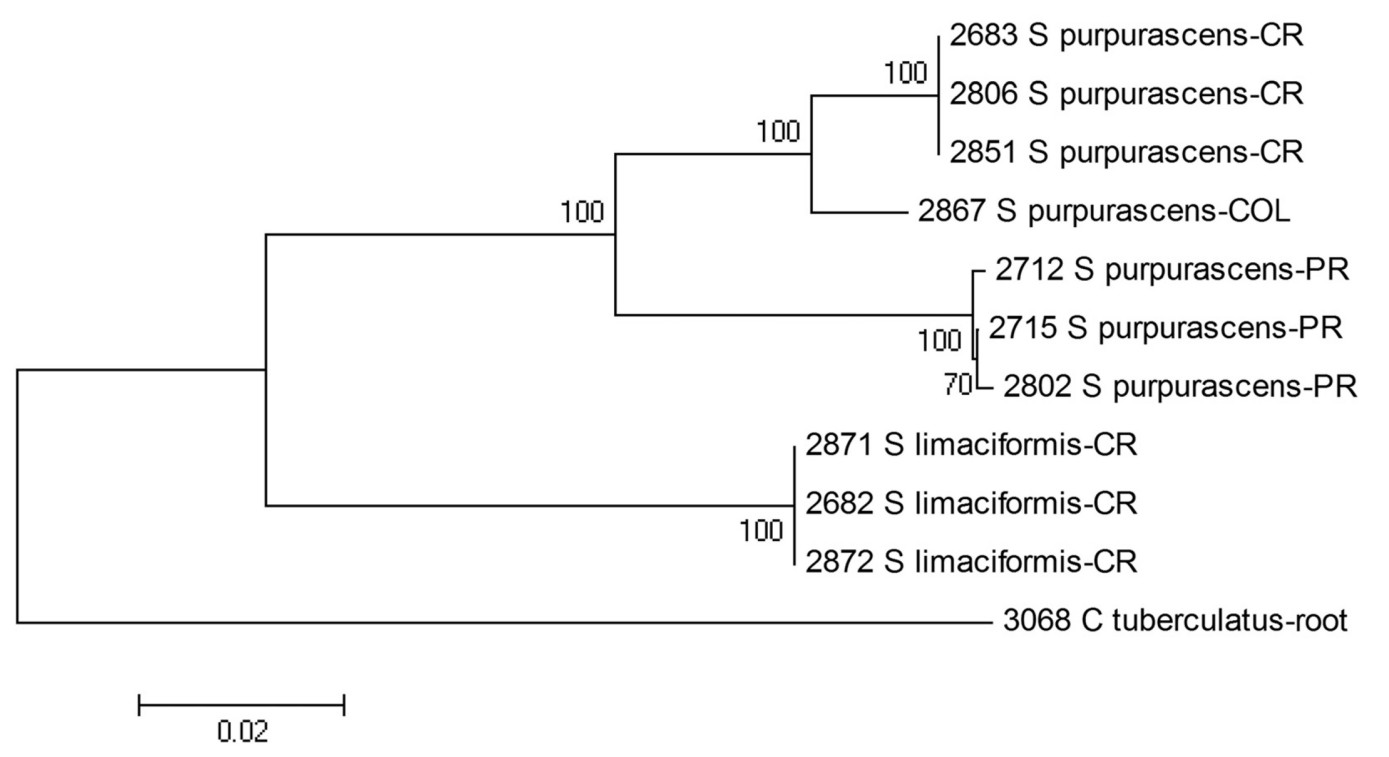

Figure 3. Phylogenetic tree for populations of S. purpurascens from the Caribbean coast of Costa Rica (CR), Colombia (COL), and Puerto Rico (PR), and S. limaciformis from the Pacific Coast of Costa Rica; based on $642 \mathrm{bp}$ of the COI gene (initial position in the 1516 bp), using nucleotide percent distance. The evolutionary relationship was inferred using the Neighbor-Joining method. Values at nodes represent the percentage of 1000 bootstrap replicates. The scale bar represent the number of substitutions per nucleotide position. Tree is rooted by Chiton tuberculatus. CR= Costa Rica, COL= Colombia, PR= Puerto Rico / Árbol filogenético de las poblaciones de S. purpurascens de la costa caribeña de Costa Rica (CR), Colombia (COL), Puerto Rico (PR) y S. limaciformis de la costa del Océano Pacífico de Costa Rica; basado en el porcentaje de distancia de 642 bp del gen mitocondrial COI (iniciando en la base 1516). La relación evolutiva se infiere usando el método vecino más cercano. El porcentaje de réplicas de las asociaciones entre taxones, a partir de un análisis de bootstrap de 1000, aparece cercano a las ramas. Chiton tuberculatus se utiliza como raíz. $\mathrm{CR}=$ Costa Rica, $\mathrm{COL}=$ Colombia, $\mathrm{PR}=$ Puerto Rico 
The comparison of 6 species of the genus Stenoplax, 4 from the Pacific and 2 from the Caribbean, showed 162 variable positions in a $515 \mathrm{bp}$ matrix $(31.5 \%)$. The lowest values of divergence between different species (11\%) correspond to $S$. purpurascens from Costa Rica and $S$ limaciformis (Table 3). On average, the base thymine is more abundant, with $36.7 \%$, followed by $26.8 \%$ adenine, guanine with $20.3 \%$, and cytosine with $16.2 \%$. A phylogenetic tree was inferred from the data on Table 3 (Fig. 4).

Table 3. Stenoplax spp. nucleotide percent distances. Below the diagonal: nucleotide percent distances calculated comparing $515 \mathrm{bp}$ (initial position in the $1574 \mathrm{bp}$ ). Above the diagonal: transition/transversion ratio, $\mathrm{nt}=\mathrm{no}$ transversion, PR= Puerto Rico, COL= Colombia, CR= Costa Rica, FL= Florida / Porcentaje de diferencias en nucleótidos entre especies del género Stenoplax. Bajo la diagonal: porcentaje de diferencias en nucleótidos comparando 515 bp (iniciando en la base 1574). Sobre la diagonal: relación de transición/transversión, nt= ninguna transversión, PR= Puerto Rico, $\mathrm{COL}=$ Colombia, $\mathrm{CR}=$ Costa Rica, FL= Florida

\begin{tabular}{lcccccccc}
\hline & 1 & 2 & 3 & 4 & 5 & 6 & 7 & 8 \\
\hline [1] \#2802 S. purpurascens-PR & & 37 & 39 & 7.1 & 1.8 & 1.3 & 1.3 & 1.3 \\
[2] \#2867 S. purpurascens-COL & $7 \%$ & & $\mathrm{nt}$ & 5.7 & 1.6 & 1.1 & 1 & 0.9 \\
[3] \#2851 S. purpurascens-CR & $8 \%$ & $2 \%$ & & 5.4 & 1.7 & 1.3 & 1.1 & 1 \\
[4] \#2872 S. limaciformis-CR & $13 \%$ & $12 \%$ & $11 \%$ & & 1.6 & 1.2 & 1 & 1.1 \\
[5] \#2852 S. floridana-FL & $16 \%$ & $16 \%$ & $16 \%$ & $15 \%$ & & 1.1 & 1 & 1.4 \\
[6] \#AY377711.1 S. alata & $15 \%$ & $14 \%$ & $15 \%$ & $16 \%$ & $17 \%$ & & 0.7 & 1.2 \\
[7] \#EF201016.1 S. mariposa & $18 \%$ & $16 \%$ & $16 \%$ & $18 \%$ & $17 \%$ & $17 \%$ & & 1 \\
[8] \#EF200986.1 S. conspicua & $18 \%$ & $15 \%$ & $16 \%$ & $16 \%$ & $16 \%$ & $15 \%$ & $16 \%$ & \\
\hline
\end{tabular}

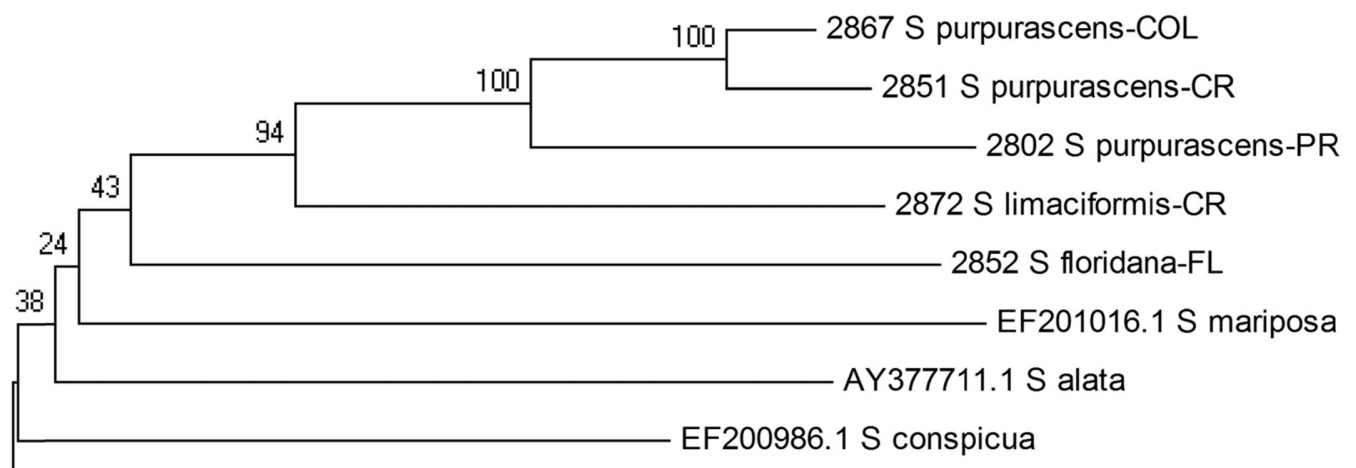

3068 Chiton tuberculatus-root

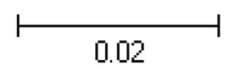

Figure 4. Phylogenetic tree of Pacific and Caribbean Stenoplax spp. based on 515 bp of the Col gene (initial position in the 1574 bp), using nucleotide percent distance. The evolutionary relationship was inferred using the Neighbor-Joining method. Values at nodes represent the percentage of 1000 bootstrap replicates. The scale bar represent the number of substitutions per nucleotide position. Tree is rooted by Chiton tuberculatus. COL= Colombia, CR= Costa Rica, PR= Puerto Rico, FL= Florida / Árbol filogenético de poblaciones de Stenoplax spp. del Pacífico y Caribe, basado en el porcentaje de distancia de 515 bp del gen mitocondrial COI (iniciando en la base 1574). La relación evolutiva se infiere usando el método vecino más cercano. El porcentaje de réplicas de las asociaciones entre taxones, a partir de un análisis de bootstrap de 1000, aparece cercano a las ramas. Chiton tuberculatus se utiliza como raíz. COL=Colombia, CR= Costa Rica, PR= Puerto Rico, $\mathrm{FL}=$ Florida 
The graph of percent genetic distance against the ratio of transitions: transversions, made with COI sequences of all Stenoplax specimens considered here suggests poor saturation before reaching $14 \%$ of divergence (Fig. 5).

An analysis of the amino acid sequence encoded by the compared gene fragments revealed that from a total of 171 amino acids, there were five variations among the 6 species compared. No differences were found in the pair S. purpurascens and S. limaciformis (all substitutions are silent). On the other hand, S. floridana differs by one amino acid (position 158 of our sequence) of the previous mentioned pair. The substitution of isoleucine (position 158 ) to valine in S. floridana (northern Caribbean species) was shared by $S$. alata (Indonesia) and S. mariposa (Eastern Pacific). Stenoplax conspicua differed from the pair of putative sister species in one amino acid (position 134). The amino acid at that position, phenylalanine, was shared by the other two species of the Pacific, but not with S. limaciformis (Table 4).

Table 4. Comparison of a partial sequence of the amino acids of the COI in some species of the Stenoplax genus / Comparación de una secuencia parcial de los aminoácidos del COI en algunas especies del género Stenoplax

\#2802_S_purpurascens-PR
\#2867_S_purpurascens-COL
\#2851_S_purpurascens-CR
\#2872_S_limaciformis-CR
\#2852_S_floridana-FL
\#AY377711.1_S_alata
\#EF201016.1_S_mariposa
\#EF200986.1_S_conspicua

\#2802_S_purpurascens-PR \#2867_S_purpurascens-COL \#2851_S_purpurascens-CR \#2872_S_limaciformis-CR \#2852_S_floridana-FL \#AY3777̄11.1 S alata \#EF201016.1_S_mariposa \#EF200986.1_S_conspicua

\#2802_S_purpurascens-PR \#2867_S_purpurascens-COL \#2851 S purpurascens-CR \#2872 S limaciformis-CR \#2852_S_floridana-FL \#AY377711.1_S_alata \#EF201016.1_S_mariposa \#EF200986.1_S_conspicua

\#2802_S_purpurascens-PR \#2867_S purpurascens-COL \#2851_S_purpurascens-CR \#2872_S_limaciformis-CR \#2852_S_floridana-FL \#AY3777111.1_S_alata \#EF201016.1_S_mariposa \#EF200986.1_S_conspicua

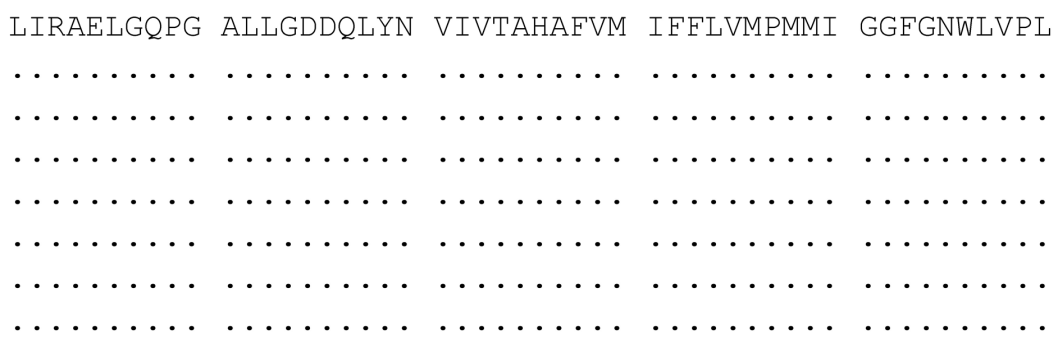

MLGAPDMAFP RLNNMSFWLL PPALCLLLGS AAVESGVGTG WTVYPPLASN

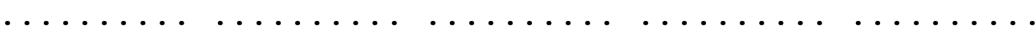

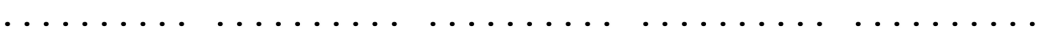

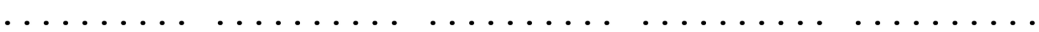

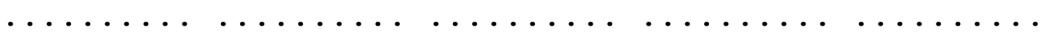

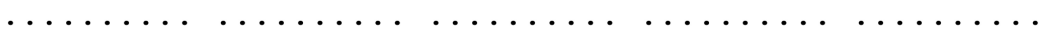

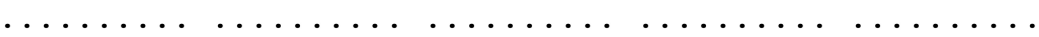

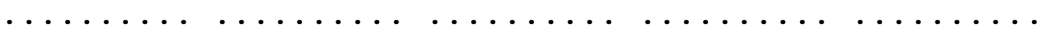

IAHAGGSVDL AIFSLHLAGV SSILGAVNFI TTVLNMRWKG MQMERLPLFV

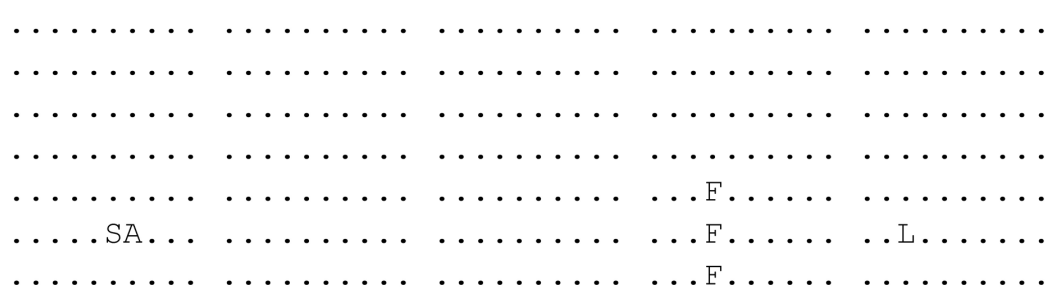

WSVKITAILL LLSLPVLAGG I

$\ldots \ldots \ldots \ldots \ldots$.

$\ldots \ldots \ldots \ldots \ldots \ldots$

$\ldots \ldots \ldots \ldots \ldots \ldots \ldots$

$\ldots \ldots v . \ldots \ldots \ldots \ldots$.

$\ldots \ldots v . \ldots \ldots \ldots \ldots$.

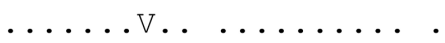

$\ldots \ldots \ldots \ldots \ldots \ldots+$ 


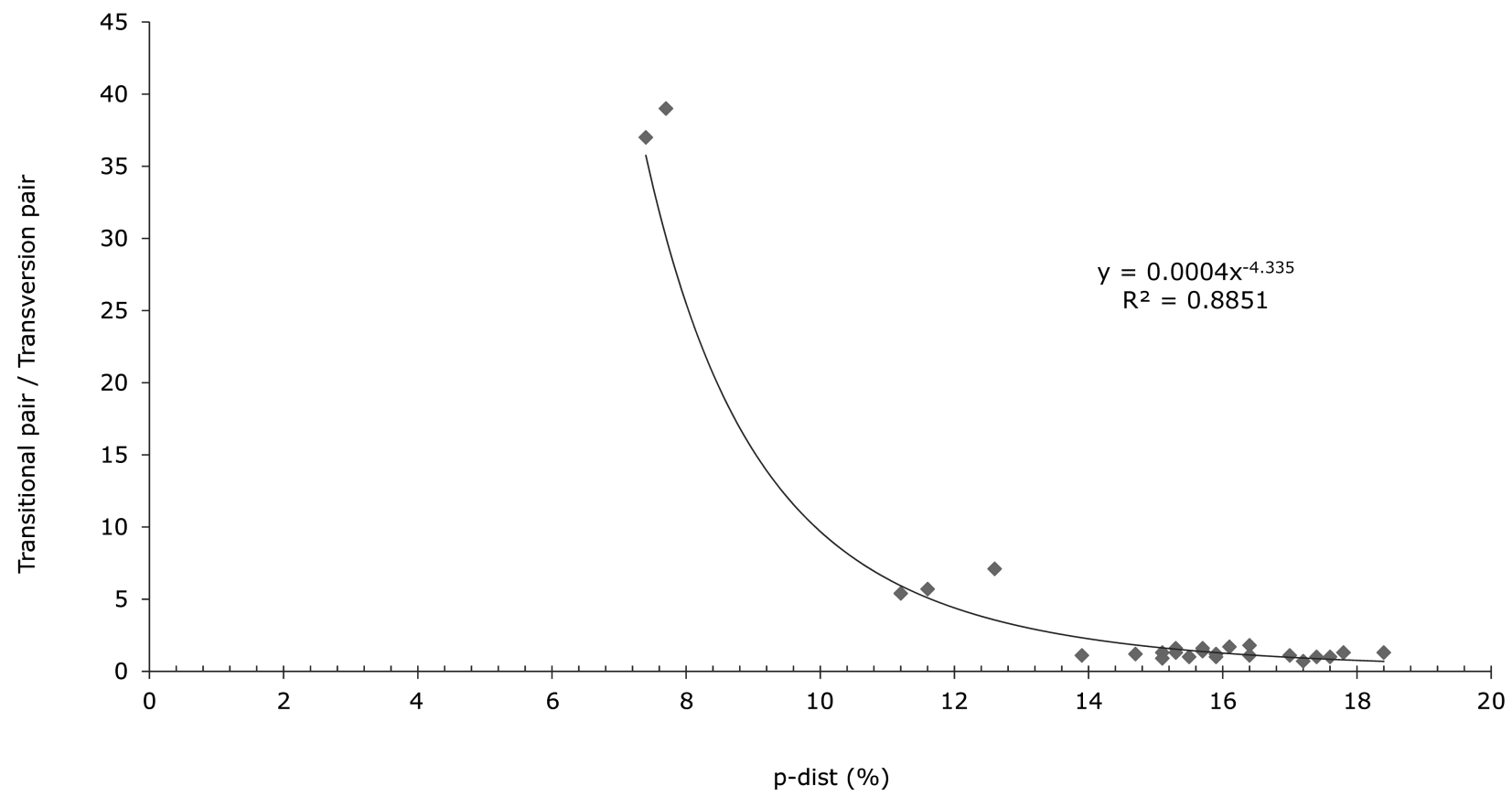

Figure 5. COI gene saturation analysis using percent distance versus transition/transversion ratio of Stenoplax spp. / Análisis de saturación del gen COI, utilizando el porcentaje de distancia versus la razón de transición/transversión de Stenoplax spp.

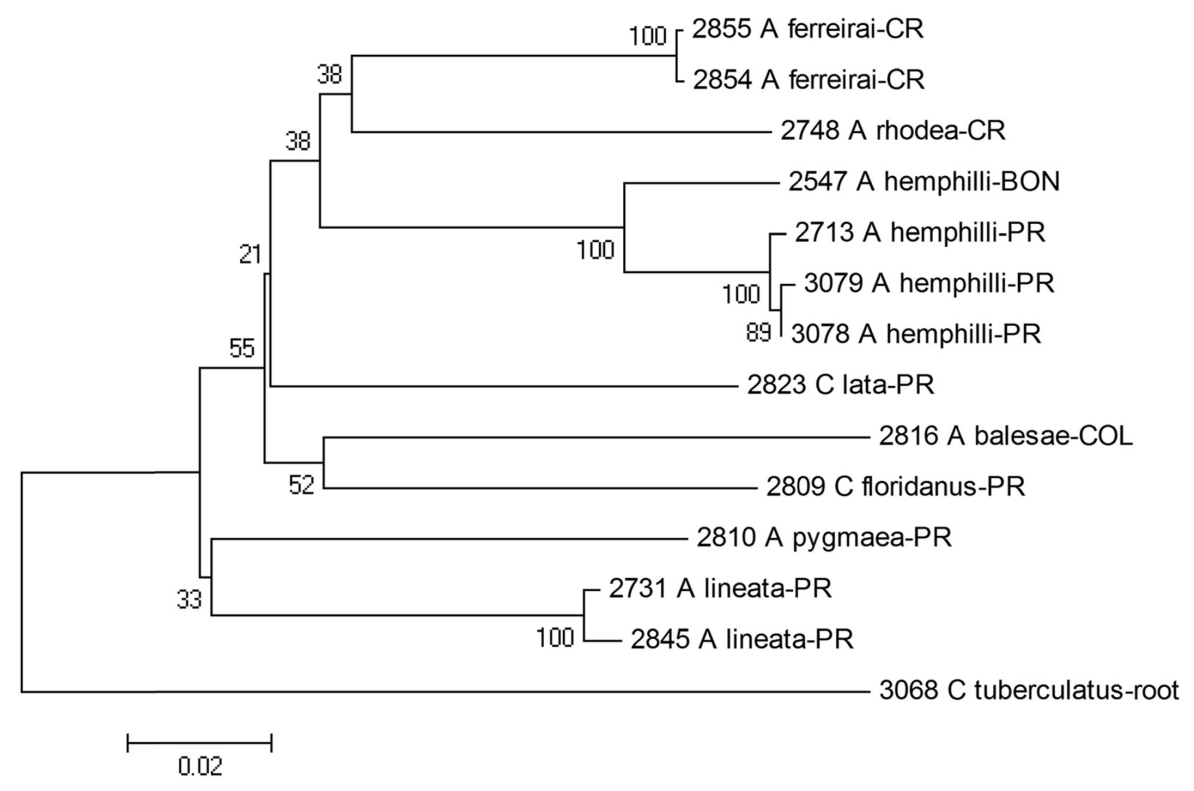

Figure 6. Phylogenetic tree for selected Acanthochitonidae species from the Caribbean and A. ferreirai from the Pacific coast of Costa Rica; based on $551 \mathrm{bp}$ of the $\mathrm{COI}$ gene (initial position in the $1562 \mathrm{bp}$ ), using nucleotide percent distance. Values at nodes represent the percentage of 1000 bootstrap replicates. The scale bar represent the number of substitutions per nucleotide position. Tree is rooted by Chiton tuberculatus. CR= Costa Rica, BON= Bonaire, PR= Puerto Rico / Árbol filogenético de especies caribeñas de la familia Acanthochitonidae y A. ferreirai de la costa del Pacífico de Costa Rica, basado en el porcentaje de distancia de 551 bp del gen mitocondrial Col (iniciando en la base 1574). La relación evolutiva se infiere usando el método vecino más cercano. El porcentaje de réplicas de las asociaciones entre taxones, a partir de un análisis de bootstrap de 1000, aparece cercano a las ramas. Chiton tuberculatus se utiliza como raíz. CR= Costa Rica, BON=Bonaire, $P R=$ Puerto Rico 
The comparison of the sequence divergence of 551 base pairs of COI in 8 species of 3 genus of the family Acanthochitonidae, shown in Fig. 6. The total number of variable positions in the comparison matrix was also large, $162(29.9 \%)$. On average, the base thymine is more abundant, with $42.3 \%$, followed by guanine $(23.0 \%)$, adenine (20.5\%), and cytosine with $14.2 \%$.
The acanthochitonids COI sequences compared encoded a total of 183 amino acids. There were only 2 variations in the amino acid sequence among the 9 species compared. Crytoconchus floridanus differs by one amino acid (position 162 of our sequence), Acanthochitona pygmaea and A. balesae differs in the 143 amino acid. The other 6 species showed identical amino acid sequence fragments (silent nucleotide substitutions) (Table 5).

Table 5. Comparison of a partial sequence of the amino acids of the COI in some species in the family Acanthochitonidae / Comparación de una secuencia parcial de los aminoácidos del COI en algunas especies de la familia Acanthochitonidae

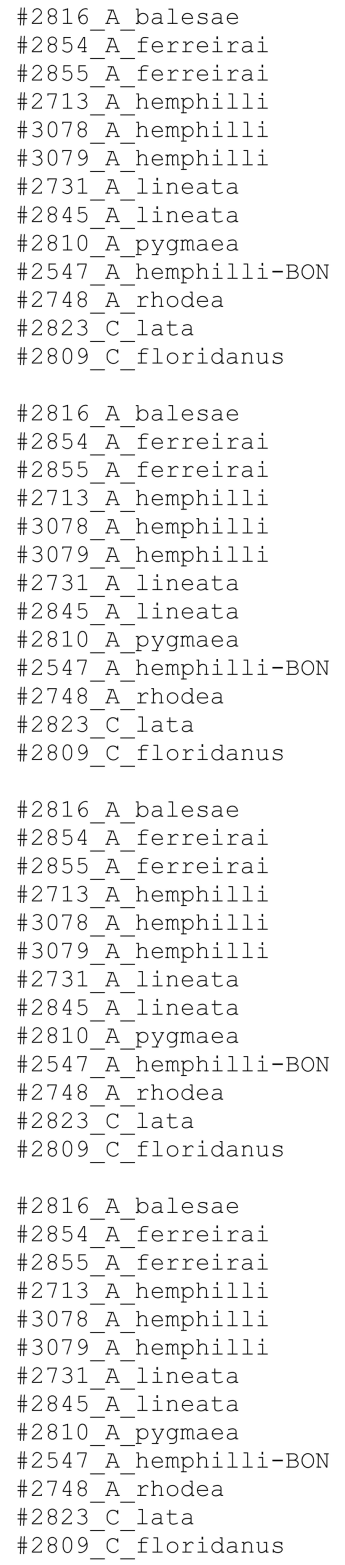

ALSLLIRAEL GQPGALLGDD QLYNVIVTAH AFVMIFFLVM PMMIGGFGNW

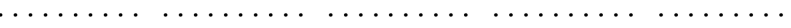


A comparison of divergence of the $590 \mathrm{pb}$ COI sequence in 8 specimens of the 3 morphologically and genetically similar Acanthochitona species was done. Three of the specimens compared belong to the species A. ferreirai (Pacific coast of Costa Rica), 4 specimens of A. hemphilli (Pilsbry 1893), 3 from Puerto Rico and one of Bonaire, and a specimen of $A$. rhodea from the Caribbean coast of Costa Rica. Sequence comparisons between the 3 species of Acanthochitona, revealed that the smallest distance found between $A$. rhodea (Caribbean Costa Rica) was with the specimens of $A$. ferreirai of the Costa Rica Pacific coast ( 10.5 to $10.4 \%, 0.002$ SE). While the distances to specimens of $A$. hemphilli of Bonaire and Puerto Rico were 12.4 and 13.2-13.6\%, respectively. Among the specimens of $A$. hemphilli of Bonaire and Puerto Rico we found a distance of 4.8-5.1\% (Table 6 and Fig. 6).

\section{Discussion}

The phylogenetic comparison between species of the genus Stenoplax (Fig. 4) and the comparison of the 171 amino acids sequence (Table 4) is consistent with the hypothesis that $S$. purpurascens and S. limaciformis are sister's species. Equally, the comparison of the sister species Acanthochitona hemphilli, A. rhodea and A. ferreirai (Fig. 6) identifies the species $A$. rhodea (Southern Caribbean) and A. ferreirai (Tropical Eastern Pacific) to be genetically closer (Table 6). This supports the hypothesis expressed by Lyons (1988: 86) of greater closeness between this pair.

The graph of genetic percent distance against the transition/transversion ratio, shows a saturation of about
$14 \%$ of divergence (Fig. 5). This is similar to the $11 \%$ reported for red algae (Sherwood et al. 2010) and much less than $20 \%$ (K2p distance) for species of shrimps of the genus Macrobrachium (Zhang et al. 2009). This limits the use of the COI gene as a molecular clock in chitons to divergences of less than $14 \%$, margin that allows the calibration of the sister species compared in this study.

Using as separation time of the populations 3.1 mya, based on the minimum estimated time that the Caribbean and Pacific faunas are thought to have been isolated by the Panamic Isthmus, then this assumed vicariance date would lead to a calculated divergence ratio of $3.7 \%$ / mya in Stenoplax (Table 2) and 3.4\% / mya in Acanthochitona (Table 6). These values correspond to $4.1 \mathrm{~K} 2 \mathrm{p}$ in Stenoplax and 3.6 K2p in Acanthochitona (Kimura 1980 method, as implemented by MEGA4).

Divergence values of 3.4 to $3.7 \%$ bp / mya calculated for these chiton species are of similar magnitude to those reported for shrimps of the genus Penaeus (3\%, Baldwin et al. 1998), Diadema echinoderms (2.9 to 4.2\%, Lessios et al. 2001) Tripneustes, Diadema and Meoma (3.5\%, Lessios et al. 2003) and higher than the $2.6 \%$ calculated for the gastropod Echinolittorina (Williams \& Reid 2004) and 1.8 to $2.2 \%$ in Eucidaris and Echinometra urchins (Bermingham \& Lessios 1993). The heterogeneous molecular evolutionary rates among taxa are well documented (e.g., Kumar 2005, Ward 2009, Morrison et al. 2004). The differences in generation time of each species could explain some of those differences. However, some of these divergence rates have been qualified as overestimates (Marko 2002), because not all marine

Table 6. Acanthochitona sister species nucleotide percent distances. Below the diagonal: nucleotide percent distances calculated comparing 590 bp (initial position in the 1550 bp). Above the diagonal: transition/ transversion ratio, $\mathrm{nt}=$ no transversion, $\mathrm{CR}=$ Costa Rica, $\mathbf{P R}=$ Puerto Rico, $\mathbf{B O N}=$ Bonaire $/$ Porcentaje de diferencias en nucleótidos entre especies hermanas del género Acanthochitona. Bajo la diagonal: porcentaje de diferencias en nucleótidos comparando 590 bp (iniciando en la base 1550). Sobre la diagonal: relación de transición/transversión, nt= ninguna transversión, $\mathrm{CR}=$ Costa Rica, $\mathrm{PR}=$ Puerto Rico, BON= Bonaire

\begin{tabular}{lccccccccc}
\hline & 1 & 2 & 3 & 4 & 5 & 6 & 7 & 8 \\
\hline [1] \#2855 A. ferreirai-CR & & $\mathrm{nt}$ & $\mathrm{nt}$ & 3.1 & 1.5 & 1.6 & 1.6 & 1.7 \\
[2] \#2811 A. ferreirai-CR & $0.0 \%$ & & $\mathrm{nt}$ & 3.1 & 1.5 & 1.6 & 1.6 & 1.7 \\
[3] \#2854 A. ferreirai-CR & $0.2 \%$ & $0.2 \%$ & & 3.1 & 1.6 & 1.6 & 1.7 & 1.8 \\
[4] \#2748 A. rhodea-CR & $10.5 \%$ & $10.5 \%$ & $10.4 \%$ & & 1.7 & 1.6 & 1.6 & 1.6 \\
[5]\#2713 A. hemphilli-PR & $10.7 \%$ & $10.7 \%$ & $10.9 \%$ & $13.6 \%$ & & $\mathrm{nt}$ & $\mathrm{nt}$ & 14.0 \\
[6]\#3078 A. hemphilli-PR & $11.0 \%$ & $11.0 \%$ & $11.2 \%$ & $13.2 \%$ & $0.3 \%$ & & $\mathrm{nt}$ & 13.0 \\
[7]\#3079 A. hemphilli-PR & $11.2 \%$ & $11.2 \%$ & $11.4 \%$ & $13.4 \%$ & $0.5 \%$ & $0.2 \%$ & & 13.5 \\
[8]\#2547 A. hemphilli-BON & $10.7 \%$ & $10.7 \%$ & $10.9 \%$ & $12.4 \%$ & $5.1 \%$ & $4.8 \%$ & $4.9 \%$ & \\
\hline
\end{tabular}


organisms might be able to keep genetic connectivity through a shallower seaway, where conditions of high sedimentation characteristic of mangroves existed prior to the end of the closing (Knowlton \& Weigt 1998).

The use of fossil record data for the calibration of molecular clocks in transisthmian sister species, has shown that times of separation for the mollusks associated with reefs and rocky coasts took place between 5.1-10.1 mya (Marko 2002). If we assume that the chitons populations were also isolated with the interruption of environments with hard-bottom and low sedimentation rates, the adjusted calibration for Stenoplax will be 2.2 to $1.1 \% /$ mya and 2.0 to $1.0 \%$ for Acanthochitona. These values of divergence ratio are similar to the $1.2 \%$ calculated for clams in the family Arcidae (Marko 2002) and 2.4\% for gastropods of the genus Tegula (Hellberg \& Vacquier 1999). Both estimates belong to mollusks that inhabit rocky bottoms, as the chitons. For multiple pairs of shrimps in the genus Alpheus a rate of $1.4 \%$ / mya was inferred by Knowlton \& Weigt (1998).

The genetic distances between individuals of the same species in different localities of the Caribbean showed values up to $8.0 \%$ in $S$. purpurascens and $4.9 \%$ in $A$. hemphilli. The specimens compared are not the most distant species within the genus; therefore higher intraspecific differences can be expected (Tables 2 and 4). These divergence values exceed the distance used to define some species (Avise 2000). Distances greater than those are found among many chitons species, according to Kelly \& Eernisse (2008). These divergence values suggest a reduced gene flow between the populations compared here, and support the early separation hypothesis.

Although rafting on floating objects as adults is possible, it is more likely that most of the dispersion depends on distances traveled during the pelagic larval stages, for at least free spawning species. Because chiton larvae are lecithotrophic (i.e., non-feeding), even those from free spawned gametes probably have a relatively short pelagic stage. Overall, the pelagic phase of the larval stage can last from hours to more than a week (Strathmann $\&$ Eernisse 1987). In culture, Mopalia spp. larvae were observed to settle in 5 to 10 days (Leise 1984, Eernisse 1988). It is assumed that the development of larvae in tropical waters is faster, which should further reduce the population connectivity (Kelly \& Eernisse 2007). Reported larval settling time for Chiton tuberculatus is 3 days, and 2 days for Acanthopleura granulata (Lewis 1960). Bullock
(1985) postulated that the pattern of distribution of chiton species in the Caribbean suggests that larvae must only remain in the plankton for a short time. Heath (1899 in Bullock 1985) reported that larvae of Stenoplax heathiana complete their free-swimming stage within $15 \mathrm{~min}$ to $3 \mathrm{~h}$ after hatching, but this species does not free spawn gametes, as most common chitons do. Instead, the female lays sticky benthic egg masses, and larvae develop within these, only emerging at a late larval stage already capable of remaining benthic without any pelagic stage. A short pelagic stage could be consistent with the high values of divergence between populations that we found, but reproduction has not been studied in any of these species. In order to calibrate molecular clocks with sister species, specimens should be collected on the coasts of the Isthmus, thus to avoid the error introduced by the variability of the gene within the geographic distribution of the species.

Using the phylogenetic trees for Stenoplax species (Fig. 3) and Acanthochitonidae family species (Fig. 6) we can establish that the distances between sister's species are very small. The morphological similarity between these species is not the product of convergence evolution of distantly related species. However, the low values of the bootstraps test for higher clades do not allow inferences on the evolutionary relationship among all the species represented. Such analysis would require the inclusion of other taxonomic gene and a more complete representation of these genera.

The rise of the Isthmus of Panama altered the chemical and physical conditions of the oceans that were separated (Glynn 1972). This event detoured the North Atlantic Equatorial Current to the north, intensifying the flow of currents in the Caribbean and the Gulf of Mexico (Berggren \& Hollister 1974, Lessios 2008), creating warmer and saltier conditions throughout the Caribbean and western Atlantic (Jackson et al. 1993). The change created a favorable scenario for the northward movement of tropical marine species. For species with limited dispersal and movement, such as chitons, the closure of the isthmus should have promoted colonization and speciation processes. As this is a recent geologic event, we expect that these speciation processes are not always reflected in distinctive morphological adaptations. The use of the COI gene can aid to identify possible cryptic species, and our calibration can estimate divergence times for these new species. 


\section{ACKNOWLEDGMENTS}

The Research Fund of the University of Puerto Rico at Humacao, allowed the first author to complete this manuscript. We appreciate the guidance and recommendations about the sampling places in Costa Rica to Dr. Ingo S. Wehrtmann, Universidad de Costa Rica. We acknowledge the assistance of Migdalia Álvarez-Ruiz (Universidad de Puerto Rico at Ponce) with the field work in Costa Rica. We appreciate the comments on early versions of the manuscript provided by Douglas Eernisse, of the University of California, Santa Cruz and Héctor L. Ayala del Río, of the Universidad de Puerto Rico at Humacao. The sequencing facilities of UPR-RP, which are supported by NCRR Grant \# P20 RR16470 AABRE, NIH-SCORE Grant \# S06GM08102, Universidad de Puerto Rico at Río Piedras, Biology Department, NSF-CREST Grant \# 0206200, NINDS U54 NS39405-SNRP. We appreciate the funding provided, for material and financial aid to students who participated in this research, by the programs 'Minority Access to Research Careers' (MARC) and 'Research Initiative for Scientific Enhancement' (RISE), NIH Grant \# 5R25GM07534803, both from UPR-Humacao.

\section{LITERATURE CITED}

Avise JC. 2000. Phylogeography: the history and formation of species, 447 pp. Harvard University Press, Cambridge.

Baldwin JD, AL Bass, BW Bowen \& WC Clark. 1998. Molecular phylogeny and biogeography of the marine shrimp Penaeus. Molecular Phylogenetics and Evolution 10: 399-407.

Berggren WA \& CD Hollister. 1974. Paleogeography, paleobiogeography and the history of circulation in the Atlantic Ocean. In: Hay WW (ed). Studies in PaleoOceanography. Society for Sedimentary Geology, Special Publication 20: 126-186.

Bermingham E \& HA Lessios. 1993. Rate variation of protein and mitochondrial DNA evolution as revealed by sea urchins separated by the Isthmus of Panama. Proceedings of the National Academy of Sciences of the United States of America 90: 2734-2738.

Bullock RC. 1985. The Stenoplax limaciformis (Sowerby, 1832) species complex in the new world (Mollusca: Polyplacophora: Ischnochitonidae). The Veliger 27(3): 291307.

Clabaut C, W Salzburger \& A Meyer. 2005. Comparative phylogenetic analyses of the adaptive radiation of the Lake Tanganyika cichlid fish: Nuclear sequences are less homoplasious but are also less informative than mitochondrial DNA. Journal of Molecular Evolution 61: 666-681.
Coates AG \& JA Obando. 1996. The geologic evolution of the Central American isthmus. In: Jackson JBC, AF Budd \& AG Coates (eds). Evolution and environment in tropical America, pp. 21-56. University of Chicago Press, Chicago.

Collin R. 2003. Phylogenetic relationships among calyptraeid gastropods and their implications for the biogeography of speciation. Systematic Biology 52(5): 618-640.

Collins LS. 1996. Environmental changes in Caribbean shallow waters relative to the closing tropical American seaway. In: Jackson JBC, AF Budd \& AG Coates (eds). Evolution and environment in tropical America, pp. 130-167. University of Chicago Press, Chicago.

Cronin TM \& HJ Dowsett. 1996. Biotic and oceanographic response to the Pliocene closing of the Central American Isthmus. In: Jackson JBC, AF Budd \& AG Coates (eds). Evolution and environmental in tropical America, pp. 76104. University of Chicago Press, Chicago.

Duda TF Jr \& E Rolán. 2005. Explosive radiation of Cape Verde Conus, a marine species flock. Molecular Ecology 14: 267-272.

Duda TF Jr \& AJ Kohn. 2005. Species-level phylogeography and evolutionary history of the hyperdiverse marine gastropod genus Conus. Molecular Phylogenetics and Evolution 34: 257-272.

Eernisse DJ. 1988. Reproductive patterns in six species of Lepidochitona (Mollusca: Polyplacophora) from the Pacific Coast of North America. The Biological Bulletin 174: $287-$ 302.

Felsenstein J. 1985. Confidence limits on phylogenies: An approach using the bootstrap. Evolution 39: 783-791.

Ferreira AJ. 1978. The chiton species described by C.B. Adams, 1845, from Jamaica. Bulletin of Marine Science 28(21): 81-91.

Ferreira AJ. 1985. Chiton (Mollusca: Polyplacophora) fauna of Barbados, West Indies, with the description of a new species. Bulletin of Marine Science 36(1): 189-219.

Folmer O, M Black, W Hoeh, R Lutz \& R Vrijenhoek. 1994. DNA primers for amplification of mitochondrial cytochrome $c$ oxidase subunit I from diverse metazoan invertebrates. Molecular Marine Biology and Biotechnology 3: 294-299.

García-Ríos CI \& M Álvarez-Ruiz. 2011. Diversidad y microestructura de quitones (Mollusca: Polyplacophora) del Caribe de Costa Rica. Revista de Biología Tropical 59(1): 129-136.

Glynn PW. 1972. Observations on the ecology of the Caribbean and Pacific coasts of Panama. Bulletin of the Biological Society of Washington 2: 13-30.

Hall TA. 1999. BioEdit: a user-friendly biological sequence alignment editor and analysis program for Windows 95/98/ NT. Nucleic Acids Symposium Series 41:95-98.

Haye PA, YK Tam \& I Kornfield. 2002. Molecular phylogenetics of mole crabs (Hippidae: Emerita). Journal of Crustacean Biology 22(4): 903-915. 
Hellberg ME. 1998. Sympatric sea shells along the sea's shore: the geography of speciation in the marine gastropod Tegula. Evolution 52: 1311-1324.

Hellberg ME \& VD Vacquier. 1999. Rapid evolution of fertilization selectivity and lysin cDNA sequences in teguline gastropods. Molecular Biology and Evolution 16: 839-848.

Jackson JB, P Jung, AG Coates \& LS Collins. 1993. Diversity and extinction of tropical American mollusks and emergence of the Isthmus of Panama. Science 260(5114): 1624-1626.

Jörger KM, R Meyer \& IS Wehrtmann. 2008. Species composition and vertical distribution of chitons (Mollusca: Polyplacophora) in a rocky intertidal zone of the Pacific coast of Costa Rica. Journal of the Marine Biological Association of the United Kingdom 88: 807-816.

Kaas P. 1972. Polyplacophora of the Caribbean region. Studies on the fauna of Curaçao and other Caribbean Islands 41(137): 1-162.

Kaas P \& RA Van Belle. 1980. Catalogue of living chitons (Mollusca: Polyplacophora), 204 pp. W. Backhuys Publisher, Rotterdam.

Keen AM. 1971. Sea shells of Tropical West America: Marine mollusks from Baja California to Peru, 1064 pp. Stanford University Press, Stanford.

Kelly RP \& DJ Eernisse. 2007. Southern hospitality: a latitudinal gradient in gene flow in the marine environment. Evolution 61: 700-707.

Kelly RP \& DJ Eernisse. 2008. Reconstructing a radiation: the chiton genus Mopalia in the north Pacific. Invertebrate Systematics 22: 17-28.

Kelly RP, IN Sarkar, DJ Eernisse \& R Desalle. 2007. DNA bar-coding using chitons (genus Mopalia). Molecular Ecology Notes 7: 177-183.

Kimura M. 1980. A simple method for estimating evolutionary rate of base substitution through comparative studies of nucleotide sequences. Journal of Molecular Evolution 16: 111-120.

Knowlton N \& LA Weigt. 1998. New dates and new rates for divergence across the Isthmus of Panama. Proceedings of the Royal Society of London Series B-Biological Sciences 265: 2257-2263.

Knowlton N, LA Weigt, LA Solorzano, DK Mills \& E Bermingham. 1993. Divergence in proteins, mitochondrial DNA and reproductive compatibility across the Isthmus of Panama. Science 260: 1629-1632.

Kumar S. 2005. Molecular clocks: four decades of evolution. Nature Reviews Genetics 6: 654-662.

Latiolais JM, MS Taylor, K Roy \& ME Hellberg. 2006. A molecular phylogenetic analysis of strombid gastropod morphological diversity. Molecular Phylogenetics and Evolution 41: 436-444.
Lee T \& DÓ Foighil. 2005. Placing the Floridian marine genetic disjunction into a regional evolutionary context using the scorched mussel, Brachidontes exustus, species complex. Evolution 59: 2139-2158.

Leise EM. 1984. Chiton integument: metamorphic changes in Mopalia muscosa. Zoomorphology 104: 337-343.

Lessios HA. 2008. The great American schism: divergence of marine organisms after the rise of the Central American Isthmus. Annual Review of Ecology, Evolution, and Systematics 39: 63-91.

Lessios HA, BD Kessing \& JS Pearse. 2001. Population structure and speciation in tropical seas: Global phylogeography of the sea urchin Diadema. Evolution 55(5): 955-975.

Lessios HA, J Kane \& DR Robertson. 2003. Phylogeography of the pantropical sea urchin Tripneustes: contrasting patterns of population structure between oceans. Evolution 57: 2026-2036

Lewis JB. 1960. The fauna of rocky shores of Barbados, West Indies. Canadian Journal of Zoology 38: 391-435.

Lyons WG. 1988. A review of Caribbean Acanthochitonidae (Mollusca: Polyplacophora) with descriptions of six new species of Acanthochitona Gray, 1821. American Malacological Bulletin 6: 79-114.

Marko P. 2002. Calibration of molecular clocks and divergence times of geminate species pairs separated by the Isthmus of Panama. Molecular Biology and Evolution 19: 20052021.

Mayr E. 1969. Principles of systematic zoology, 428 pp. McGraw-Hill, New York.

Miura O, ME Torchin \& E Bermingham. 2010. Molecular phylogenetics reveals differential divergence of coastal snails separated by the Isthmus of Panama. Molecular Phylogenetics and Evolution 56: 40-48.

Morrison CL, R Rios \& JE Duffy. 2004. Phylogenetic evidence for an ancient rapid radiation of Caribbean sponge-dwelling snapping shrimps (Synalpheus). Molecular Phylogenetics and Evolution 30: 563-581.

Roe AD \& FAH Sperling. 2007. Patterns of evolution of mitochondrial cytochrome c oxidase I and II DNA and implications for DNA barcoding. Molecular Phylogenetics and Evolution 44(1): 325-345.

Saitou N \& M Nei. 1987. The neighbor-joining method: A new method for reconstructing phylogenetic trees. Molecular Biology and Evolution 4: 406-425.

Schubart CD, R Diesel \& SB Hedges. 1998. Rapid evolution to terrestrial life in Jamaican crabs. Nature 393: 363-365.

Sherwood AR, T Sauvage, A Kurihara, KY Conklin \& GG Presting. 2010. A comparative analysis of COI, LSU and UPA marker data for the Hawaiian florideophyte Rhodophyta: implications for DNA barcoding of red algae. Cryptogamie Algologie 31(4): 451-465. 
Smith AG. 1961. Four species of chitons from the Panamic Province (Mollusca: Polyplacophora). Proceedings of the California Academy of Science 30(4): 81-90.

Strathmann M \& DJ Eernisse. 1987. Phylum Mollusca, Class Polyplacophora. In: Thorpe SR (ed). The Friday Harbor Labs Handbook of Marine Invertebrate Embryology, pp. 205-219. University of Washington Press, Seattle.

Tamura K, J Dudley, M Nei \& S Kumar. 2007. MEGA4: Molecular Evolutionary Genetics Analysis (MEGA) software version 4.0. Molecular Biology and Evolution 24: 1596-1599.

Thompson JG, DG Higgins \& TJ Gibson. 1994. CLUSTAL $\mathrm{W}$ : improving the sensitivity of progressive multiple sequence alignment through sequence weighting, positionspecific gap penalties and weight matrix choice. Nucleic Acids Research 22: 4473-4680.
Ward RD. 2009. DNA barcode divergence among species and genera of birds and fishes. Molecular Ecology Resources 9: 1077-1085.

Watters GT. 1981. Two new species of Acanthochitona from the new world (Polyplacophora: Cryptoplacidae). Nautilus 95(4): 171-177.

Williams ST \& DG Reid. 2004. Speciation and diversity on tropical rocky shores: a global phylogeny of snails of the genus Echinolittorina. Evolution 58: 2227-2251.

Zhang Q, Q Cheng \& W Guan. 2009. COI gene sequence of three Macrobrachium species. Zoological Research 30(6): 613-619.

Received 19 June 2013 and accepted 1 April 2014

Associate Editor: Gabriela Muñoz C. 